\title{
MEMBUMIKAN SANG SURYA: S.D. MHD. ILYAS SANG FOUNDER MUHAMMADIYAH PARIAMAN TAHUN 1929-1941
}

\author{
Fikrul Hanif Sufyan \\ Pendidikan Sejarah STKIP Abdi Pendidikan \\ E-Mail: fikrulhanifsufyan@gmail.com
}

\begin{abstract}
Abstrak
Sidi Mhd. Ilyas merupakan sosok lokal pengembang Muhammadiyah yang belum pernah muncul dalam historiografi Pariaman, terutama pada episode modernisasi Islam di awal abad ke-20. Ilyas cs memberanikan diri untuk meluaskan pengaruh Muhammadiyah di tengah basis masyarakat penganut Tarekat Syattariyah. Penelitian ini bertujuan untuk membingkai strategi Ilyas dalam menyebarluaskan Muhammadiyah, termasuk ketika berhadapan dengan pemerintah jajahan. Metode historis yang diterapkan dalam penelitian ini terdiri atas pengumpulan sumber (heuristik). Setelah heuristik, dilakukan kritik terhadap sumber temuan; interpretasi; dan historiografi. Tradisi keagamaan Syattariyah sejak abad ke-17 di pesisir Barat Pariaman, memang tidak terbantahkan. Sampai gelombang modernisasi Islam dibawa Adnan ke Nagari Kurai Taji melalui Surau Paninjauan, telah merusak rust en orde kalangan ulama Syattariyah. Adalah Ilyas yang kemudian melanjutkan gerakan modernisasi Islam melalui Muhammadiyah Groep Kurai Taji. Beragam strategi diterapkannya, baik ketika berhadapan dengan pengikut Syattariyah, maupun berhadapan dengan pemerintah Kolonial Belanda. Setelah Ilyas memutuskan hijrah ke Kisaran, namun perhatiannya terhadap gerak Muhammadiyah Pariaman tetap tidak berubah. Konkritnya, Ilyas telah meletakkan fondasi kuat, yang kemudian dilanjutkan pemimpin persyarikatan berikutnya.
\end{abstract}

Kata kunci: Ilyas, biografi, Muhammadiyah, Syattariyah, Pariaman.

\begin{abstract}
Sidi Mhd. Ilyas is a local figure of Muhammadiyah developer who had never appeared in Pariaman's historiography, especially in the episode of modernization of Islam in the early 20th century. Ilyas cs ventured to expand the influence of Muhammadiyah in the middle of the community base of the Syattariyah Tarekat adherents. This study aims to frame the strategy of Ilyas in disseminating Muhammadiyah, including when dealing with colonial governments. The historical method applied in this study consists of heuristic collection. After heuristics, criticism is made of the source of the findings; interpretation; and historiography. Syattariyah religious tradition since the 17th century on the West coast of Pariaman, is undeniable. Until the wave of modernization of Islam Adnan brought to Nagari Kurai Taji through the Surau Paninjau, it had destroyed the rust en orde of the Syattariyah ulamas. It was Ilyas who then continued the Islamic modernization movement through Muhammadiyah Groep Kurai Taji. Various strategies were implemented, both when dealing with Syattariyah followers, and dealing with the Dutch colonial government. After Ilyas decided to move to Kisaran, his attention to Muhammadiyah Pariaman's movement remained unchanged. Concretely, Ilyas has laid a strong foundation, which is then followed by the next union leader.
\end{abstract}

Keywords: Ilyas, biography, Muhammadiyah, Syattariyah, Pariaman.

PENDAHULUAN

Memasuki awal abad ke-20, lembaran sejarah Pariaman diwarnai dengan gerakan puritanism, yang ditandai dengan munculnya surau dan tokoh-tokoh yang mengusung pembaruan Islam. Dan bila ditelisik lebih jauh, dalam historiografi Islam khususnya di Pariaman, jarang diungkap mengenai usaha modernisasi Islam di 
tengah komunitas Tarekat Syattariyah. Dalam sumber-sumber bacaan sejarah, juga tidak pernah memunculkan seorang penggerak pembaruan Islam yang kesehariannya berprofesi sebagai saudagar, maupun pemborong/ kontraktor (aannemer).

Sidi Mhd. Ilyas, lelaki kelahiran tahun 1910 (Surat Keputusan Menteri Urusan Veteran No.85/ G/KPTS/MUV.1967 tanggal 30 Desember 1967), barangkali memenuhi ruang kosong yang ditinggalkan banyak penulis sejarah, terutama dalam periode abad ke-20. Semasa hidupnya, Ilyas pernah menjadi aannemer bangunan, sepanjang hayatnya mentasbihkan dirinya untuk Muhammadiyah, dan sampai akhir hidupnya tetap mengayomi umat melalui ceramah pegajian.

Laki-laki kelahiran Nagari Sunur District Pariaman -dibesarkan di lingkungan budaya dan tradisi kegamaan tarekat Syattariyah yang masih kental, dan berpusat di Ulakan. Di tengah suasana kejumudan, kakak kandungnya bernama Adnan gelar Tuanku Itam Ketek, malah melakukan dobrakan terhadap nuansa Islam tradisional yang sudah terbangun seabad lebih.

Spirit modernisasi Islam inilah yang selanjutnya ditularkan kepada Ilyas, melalui pengajian Tuanku Itam Ketek di Surau Paninjauan pada tahun 1923. (Manuskrip Asmak Bakry, 2010: 1). Lima tahun kemudian, Ilyas yang diduga sudah

bersentuhan

dengan Muhammadiyah Cabang Padang Panjang, mengikuti pelatihan padvinder Hizbul Wathan di Yogyakarta, sekaligus mendalami Kemuhammadiyahan melalui K.H. Ahmad Dahlan pada tahun 1928 (Gemma Muhammadiyah, Juni 1975). Setahun bermukim di Kauman, Ilyas kembali ke tanah kelahirannya untuk sesegera mungkin mendirikan Muhammadiyah Ranting Kurai Taji. Sebelum resmi berdiri pada 25 Oktober 1929, Ilyas CS harus menghadapi rintangan berat dari ulama dan massa pendukung tarekat Syattariyah (Sufyan, 2003: 2).

Sejak berhasil merintis Muhammadiyah Ranting Kurai Taji, nama SDM. Ilyas pun makin berkibar, terutama ketika Kongres Muhammadiyah ke-18 diselenggarakan di Bukittinggi tahun 1930. Untuk kali pertama, Ilyas menjadi utusan istimewa mewakili Groep Kurai Taji dan membawa belasan anak yatim tampil dalam acara pembukaan kongres termeriah sepanjang Kolonial Belanda (Hofdcomite Congres Moehammadijah Djogjakarta 1930: 9).

Sempat merantau selama 11 tahun di Kisaran Sumatra bagian Timur, Ilyas memboyong kembali keluarganya ke Kurai Taji. Saat itu, status Muhammadiyah telah beralih sebagai Cabang dan membawahi belasan Groep. Membesarkan Muhammadiyah Pariaman 
pada masa pendudukan Jepang, bukanlah perkara gampang.

Ketua Cabang Muhammadiyah Pariaman itu harus menjalankan strategi ganda. Ketika militer Jepang memerintahkan Kinro Hoshi di sekitar Kurai Taji, Ilyas membolehkan anggota persyarikatan untuk mengikutinya. Namun, bila diperintahkan untuk kegiatan romusha di lubang Jepang Bukittinggi, ataupun menukar bantalan kereta api, ia pun memakai taktik untuk mengalihkan perhatian Jepang. Di tengah politik anomali, hubungan Muhammadiyah Pariaman dan Jepang mengalami pasang surut. Sampai tahun 1943, Ilyas pun dijebloskan di penjara Pariaman dengan tuduhan melakukan tindak perlawanan terhadap tentara Jepang.

Strategi yang diterapkan lulusan Tweede Klas School Kurai Taji itu dalam membumikan persyarikatan Muhammadiyah di tengah basis massa fanatik Tarekat Syattariyah itu, menarik untuk disimak. Jiwa dan spiritnya dalam membesarkan Muhammadiyah, memang cendrung berbeda dengan pimpinan persyarikatan pada masa kini. Bila pada masa kini pengurus Muhammadiyah cendrung abai terhadap organisasi yang membesarkan dirinya, namun tidak dengan Ilyas. Hampir seluruh hidupnya tercurah untuk tourne dan mendirikan ranting di setiap nagari, dan mendermakan keuntungan bisnisnya untuk Muhammadiyah Pariaman.

Untuk mengungkap lebih jauh sisi aktvitasnya, ada beberapa item pertanyaan yang bisa diajukan, bagaimana riwayat masa kecil M.Ilyas dan pengaruh latar budaya Pariaman terhadap pribadinya?, dan bagaimana kiprah SDM. Ilyas mendirikan Muhammadiyah Pariaman pada masa Kolonial Belanda dan Jepang?, Keseluruhan item pertanyaan di atas, akan terjawab dalam bahasan berikutnya.

Aspek yang mendasari penekanan tulisan ini adalah kenyataan yang menunjukkan, kajian intelektual yang menulis tokoh-tokoh lokal Muhammadiyah relatif minim. Kalaupun ada, tulisan itu ditulis sendiri oleh si tokoh. Kasim Munafy dalam manuskripnya berjudul Muhammadiyah yang Aku Kenal merupakan manuskrip awal yang mengisahkan peran SDM Ilyas merintis Muhammadiyah ranting Kurai Taji bersama Oedin, Haji Haroen el Maany, dan lainnya. Namun, dalam manuskripnya, Kasim tidak gamblang mengulas peran SDM. Ilyas dalam membesarkan Muhammadiyah Pariaman.

Beberapa karya lain, seperti tulisan Asmak Bakri yang tidak diterbitkan, berjudul Sejarah Aisyiyah di Pariaman dan Sekitarnya, sedikit menyinggung peran SDM. Ilyas dalam merintis Muhammadiyah Kurai Taji. 
Namun, dalam tulisannya, Asmak lebih banyak mengulas peran isteri SDM. Ilyas, yakni Rohana dalam merintis dan membesarkan Aisyiyah Pariaman.

Tulisan lainnya terdapat dalam skripsi sejarah berjudul, Organisasi Muhammadiyah Daerah Padang Pariaman Masa Orde Baru (1967-1998) ditulis oleh Fikrul Hanif Sufyan. Dalam tulisannya, Fikrul hanya beberapa kali menyebut nama SDM Ilyas, terutama melihat peran SDM Ilyas menggagas berdirinya Muhammadiyah di Kurai Taji.

Tulisan yang lebih banyak mengisahkan SDM Ilyas ditemukan dalam buku yang tidak diterbitkan, berjudul Keluarga Besar Haji Sidi Muhammad Ilyas disusun oleh Ardin Ichwan. Buku yang dicetak oleh keluarga besar Ilyas ini, berisi kolektif memori dari anakanak, menantu mengenai sosok dan sepak terjang SDM Ilyas semasa hidupnya. Tulisan ini tentu saja, banyak membantu dalam penulisan biografi komprehensif SDM Ilyas. Dari beberapa dokumen sejarah yang ditemukan, buku yang tidak diterbitkan, dan skripsi sejarah, dipastikan bahwa potret kehidupan SDM Ilyas dalam bentuk biografi komprehensif belum ada yang menulis.

Tulisan mengenai Potret Kehidupan SDM. Ilyas pada dasarnya erat hubungannya dengan konsep biografi dan kepemimpinan. Penulisan biografi merupakan suatu usaha untuk menggambarkan dan memperkenalkan seseorang melalui kisah hidupnya. Menurut Kuntowijoyo (2003) menegaskan bahwa sejarah adalah kumpulan biografi. Oleh karena itu model ini sangat digemari oleh sejarawan penganut Hero in History. Mereka yang memilih model ini perlu menyadari bahwa kepribadian seseorang dapat dipelajari melalui latar belakang keluarga, pendidikan, lingkungan sosialbudaya, dan perkembangan diri.

Kepribadian seseorang, menurut Sartono Kartodirdjo (1992: 45) dapat dipahami dan didalami dengan cara mempelajari latar belakang lingkungan sosio-kultural di mana tokoh itu dibesarkan, bagaimana proses pendidikan formal dan informal yang dialami, dan watak-watak orang yang ada di sekitarnya. Sedangkan menurut Kuntowijoyo penting pula menceritakan tikungan-tikungan yang menentukan jalan hidup selanjutnya dan membawa perubahan penting. sejarah.

Selanjutnya, masih menurut Kuntowijoyo yang juga perlu diperhatikan dalam kerangka teoretik adalah metodologi. Dari sudut pandang metodologi, ada dua macam biografi, yaitu portrayal (potret) dan scientific (ilmiah), yang masing-masing mempunyai metodologi sendiri. Biografi potret hanya mencoba memahami tokoh sebagaimana yang diceritakannya, 
misalnya biografi politik, bisnis, seni, olah raga, dan sebagainya.

Abdurrahman Surjomihardjo (1985: 40) mengatakan seorang penulis biografi harus mampu membuat lukisan kehidupan dan penghidupan tokoh dengan berlatar-belakang peristiwa yang jelas, peristiwa pribadi, lokal, nasional, maupun internasional. Dalam penguraiannya, mesti dihindari suatu deskripsi yang bersifat kronologis. Sebuah biografi yang baik, harus mampu memaparkan kegemaran (hobi), humor, ucapan yang khas, pendapat, dan pandangan mengenai pengalaman yang unik, cita-citanya dalam kehidupan keluarga dan masyarakat.

Sagimun M.D (1992: 40) menyatakan bahwa dalam penulisan biografi ditekankan pada life and time. Life, merupakan bagian yang membicarakan watak, sifat-sifat, kesenangan-kesenangan, kegemarankegemaran dari tokoh yang ditulis. Sedangkan time, membicarakan peristiwa-peristiwa sejarah yang erat kaitannya dengan tokoh. Artinya, tokoh harus ditempatkan dalam konteks sejarah di masa mana ia hidup dan berjuang. Maka dalam penulisan biografi supaya menghindari sikap hero-worship, yakni penyembah-an dan pemujaan kepada tokoh. Seluruh teori yang berhubungan dengan biografi ini akan digunakan untuk menganalisis tingkat motivasi dan besaran upaya Ilyas dalam persyarikatan Muhammadiyah dan aktivitas lainnya dalam ruang dan waktu.

Membicarakan aktifitas Sd.Mhd. Ilyas di pentas Muhammadiyah, tidak dilepas dari konsep kepemimpinan. Kepemimpinan merupakan salah satu faktor utama yang mendukung kesuksesan organisasi dalam mencapai tujuan (Gibson, 1996: 6). Keith Devis merumuskan empat sifat umum yang berpengaruh terhadap keberhasilan kepemimpinan organisasi, antara lain kecerdasan, kedewasaan, motivasi diri, dan sifat hubungan kemanusiaan.

Menurut Mohammad Djazman dalam artikelnya berjudul Kepemimpinan dalam Muhammadiyah, menegaskan bahwa kepemimpinan di organisasi modernis Islam tersebut mempunyai ciri-ciri: mampu memahami diri sendiri, mampu melakukan komunikasi, mempunyai kesadaran dalam menambah ilmu, mampu mengembangkan sikap ulamanya (Suara Muhammadiyah No.13/62, 1982: 15). Secara tegas syarat yang harus dipenuhi oleh seorang pemimpin Muhammadiyah adalah memahami konsep dasar di Muhammadiyah, yakni Matan Keyakinan dan Cita-cita Hidup Muhammadiyah, Kepribadian Muhammadiyah dan Mukadimah AD Muhammadiyah.

\section{METODE PENELITIAN}

Penelitian ini menggunakan Metode historis. Penelitian ini terdiri 
atas pengumpulan sumber (heuristik). Setelah heuristik, dilakukan kritik terhadap sumber temuan; interpretasi; dan historiografi.

\section{HASIL DAN PEMBAHASAN}

Sunur dan Kurai Taji: Masa Pembentukan Karakter, Pendidikan, dan Perjumpaan Sidi Mhd. Ilyas dengan Muhammadiyah

Muhammad Ilyas, demikian nama lengkap laki-laki kelahiran Nagari Sunur tahun 1910. Terlahir dari pasangan Muh. Umar (Katik Ma' Uma) dan Aminah. Sebagaimana lazimnya budaya di ranah Minang, bahwa garis keturunan mengikuti ibu, sehingga suku dari Ilyas adalah Koto dari balahan nagari Sunur.

Pada awalnya Sunur dan Kurai Taji adalah satu nagari. Namun karena penduduk Kurai Taji makin banyak, Sunur pun memisahkan diri dan menjadi nagari sendiri. Wilayah Sunur meliputi beberapa korong, yakni Kampung Kandang-Koto Gadis, Koto Rajo-Koto Marapak-Kampung Aur, Kampung Tangah, Taluak Nibung, Tingkalak, Kampung Jambak, Pasar Baru, Pintir Kayu, Padang Kalam, Olo, Pakoktan, Kabun, Pautan Kabau, dan Kampung Lintang (Suryadi, 2001).

Tradisi lisan Sunur, mengisahkan bahwa asal usul mereka berasal dari Luhak Tanah Datar, dengan sistem Kelarasan Koto Piliang. Nagari Sunur dihuni oleh lima suku, di antaranya
Koto, Jambak, Guci, Sikumbang, Panyalai, dan Tanjung. Dari lima suku tersebut, diketahui bahwa Ilyas yang mengikuti garis Koto merupakan suku awal di Nagari Sunur.

Masih dalam kisah tradisi lisan Sunur, sebagai bagian dari rantau bagian baratnya Minangkabau, nagari ini mempunyai Raja Kecil bernama Maharajo Nando. Keberadaaan raja-raja kecil ini tergantung kepada kepiawaian mereka membina hubungan dagang dengan para pendatang, mulai dari hadirnya Aceh tetapi kemudian disusul dengan kedatangan Belanda dan Inggris (Kathirithamby, 1969). Menurut sebuah laporan tahun 1730, Sunur dipimpin oleh tiga orang, yakni Orang Kaya Besar, Maharaja Nanda, dan Sri Maharaja. Hingga lebih dari dua dekade kemudian, struktur kekuasaan seperti itu tetap dipertahankan di Sunur yang membawahi lima dusun

Catatan-catatan dari Memorandum van Overgave (MvO) menunjukkan, Sunur punya peranan penting dalam produksi garamnya. MvO juga mencatat, bahwa Sunur sering didatangi orangorang dari Darek (dataran pedalaman Minangkabau) yang datang ke pantai barat, untuk membeli garam (Colombijn, 1996). Ketika pemerintah Kolonial Belanda menerapkan kebijakan monopoli perdagangan garam sejak abad ke-18, Sunur ikut terkena dampaknya. Untuk menjaga kestabilan harga, 
seringkali Kompeni memusnahkan produksi garam di Sunur dan sekitarnya yang dijalankan oleh regent setempat.

Pada masa Padri, dalam catatan Dobbin (1974), Sunur menjadi basis pertahanan terdepan dalam menghadang Kompeni. Pada masa itu, Sunur menjadi benteng untuk masyarakat VII Koto untuk menahan serangan Kompeni dari arah laut pada November 1819. Ujung dari perlawanan iu, Maharajo Nando- sang raja kecil Sunur beserta 18 orang pemimpin lainnya di rantau Pariaman menyerahkan kekuasannya kepada Kompeni. Pasca penaklukannya, 800 jiwa masyarakat Sunur dipimpin seorang Muncak yang dibantu oleh enam orang penghulu.Kisah keemasan Sunur tentu mempunyai pengaruh yang cukup besar dalam membentuk karakter Ilyas sedari kecilnya. Daerah yang terletak di pesisir Sumatra Westkust dicatat Tomé Pires dalam Suma Oriental menjadi bagian dari kawasan Pariaman (Cortesão, 1944).

Pembentukan karakter pribadi Ilyas sendiri telah dibangun dalam pegaruh kultur Pariaman yang unik. Sebagai kawasan rantau dan pernah dikuasai Aceh sebad lamanya, untuk panggilan untuk seseorang masih tetap dipertahankan hingga kini. Seorang lakilaki yang lebih dewasa umurnya, alan dipanggil ajo (raja), sedangkan untuk kakak perempuan disebut cik uniang. Dan sebagian lainnya dari orang Pariaman ada yang mempertahankan panggilan uda (lelaki) dan uni (perempuan)- sebagai hasil pengaruh kawasan Darek.

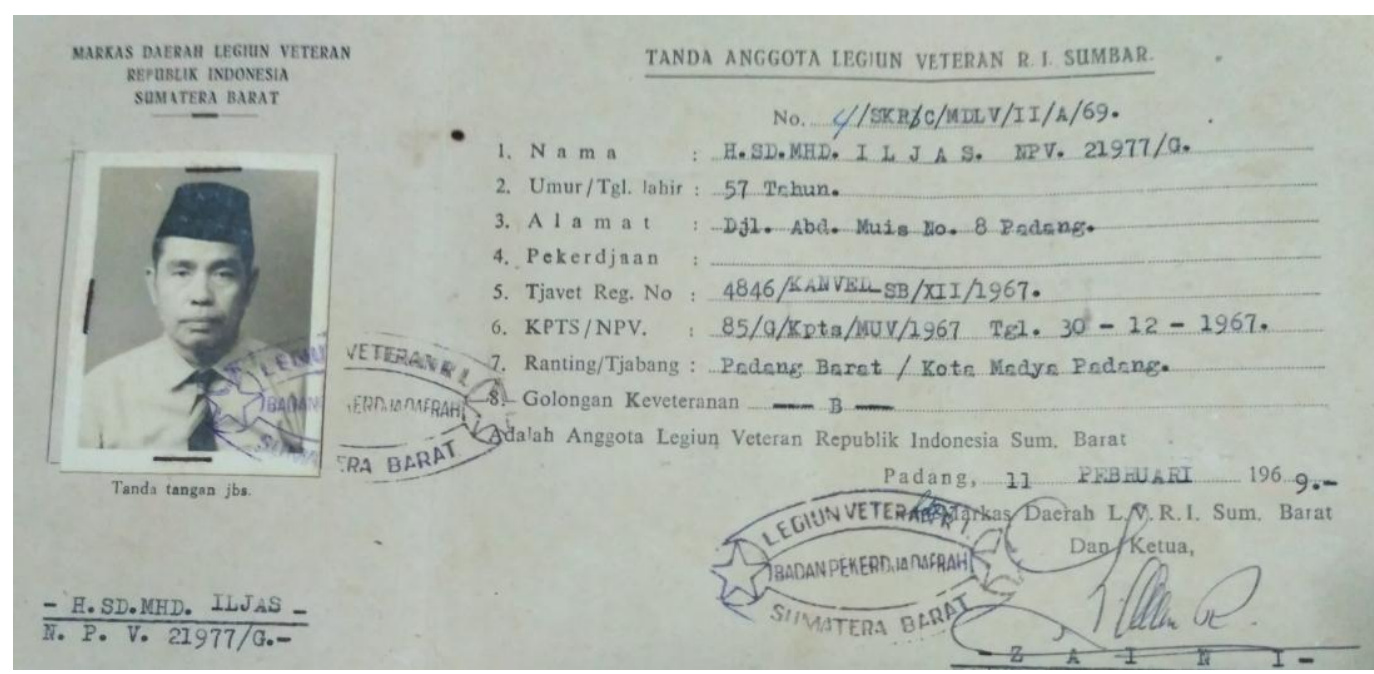

Gambar 1. Tanda anggota Legiun Veteran atas nama Sidi Mhd. Ilyas yang dikeluarkan tanggal 11 Februari 1969. Ilyas (1910-1971) semasa hidupnya dikenal sebagai founder Muhammadiyah Pariaman dan menyebarluaskan Islam reformis hingga ke pelosok nagari. Sumber: Arsip dokumentasi Rusjdi Ilyas.

Pengaruh kuat budaya Pariaman lainnya dalam diri Ilyas adalah pendidikan
Surau- yang memengaruhi pembentukan struktur pengalaman seseorang. Clifford 
Geertz dalam Mrazek (1972:2) menulis, bahwa struktur pengalaman merupakan akumulasi total dari pola budaya, simpulan simbol-simbol yang telah dibangun masing-masing orang dari berbagai peristiwa yang telah dialami, sebagaimana terwujud pada struktur konsep simbolik yang dapat dirasakan setiap orang. Struktur pengalaman itulah yang dirasakan Ilyas ketika dibina oleh kakak kandungnya bernama Adnan gelar Tuanku Itam Ketek di Surau Paninjauan Nagari Kurai Taji.

Tuanku Itam Ketek, memang minim ditemukan dalam literatur historiografi Pariaman pada awal abad ke-20. Hanya tiga sumber tertulis yang menyebut nama tokoh modernisasi Islam asal Pariaman ini, yakni Yunus (1970), Munafy (1979), dan Bakry (2010). Yunus (1970: 144) mengungkap Adnan merupakan murid dari tokoh Syekh $M$. Thaib Umar asal Simabur Luhak Tanah Datar. Selepas belajar dengan Thaib Umar, Adnan mendalami Islam di Mekah (tahun??) - selanjutnya menyebar pembaruan Islam di Nagari Kurai Taji. Munafy (1979) menulis, Adnan di kalangan masyarakat Kurai Taji disebut sebagai urang mudo, ataupun urang maju-atau identik dengan sebutan Kaum Muda sebagaimana dipopulerkan oleh Taufik Abdullah (1971).

Di Surau Paninjauan, Adnan menyebar paham pembaruan Islam yang banyak ditentang oleh kalangan Islam
Tradisional-tarekat

Syattariyah. Schrieke (1973) menulis, sejak pantai Barat Sumatra dikuasai Aceh lebih seabad lamanya, Islam berbasis tarekat Syattariyah telah menguat di Ulakan Pariaman di bawah pengaruh Syekh Burhanuddin, kemudian tersebar luas di Koto Tangah Padang, Pulut-pulut Bayang Pesisir Selatan, Sirukam dan Supayang Solok, Padang Ganting dan Koto Lawas Luhak Tanah Datar, hingga ke rantau Sijunjung.

Uniknya di tengah komunitas fanatik Syattariyah, perjuangan Adnan menyebar Islam reformis itu disupport dua orang saudagar kaya Kurai Taji, yakni Haji Mangan, Haji Abdul Madjid Latif, dan Bagindo Mhd. Nur. Selain Ilyas, beberapa orang murid terbaik Adnan yang nantinya melanjutkan usaha modernisasi Islam melalui Muhammadiyah adalah Haroen el-Maany (direktur Kulliyatul Muballighin Muhammadiyah dan Ketua Muhammadiyah Sumatra Barat tahun 1960), Oeddin (Ketua Muhammadiyah Pariaman 1930an), Sulaiman Munafy (Direktur MTs Muhammadiyah 19301990), Kasim Munafy (Ketua Muhammadiyah Daerah Pariaman 19501991), Umar Ganti (pengajar Muallimin Muhamamdiyah dan Pendidikan Ulama Zuamma Kurai Taji), dan lainnya.

Selepas belajar di Surau Paninjauan, lulusan Tweede Klas School itu diduga mengikuti pengkaderan dari 
Ahmad Rasjid Sutan Mansur yang telah bermukim di Padang Panjang sejak tahun 1926 (Sufyan, 2014). Di sinilah titik awal perjumpaan Ilyas dengan persyarikatan Muhammadiyah. Dua tahun kemudian, Ilyas direkomendasikan Buya Sutan Mansur untuk mengikuti pengkaderan padvinder Hizbul Wathan di Yogyakarta tahun 1928. Dengan menumpang kapal Koninklijke Paketvaart Maatschappij (KPM), Ilyas berangkat dari Pelabuhan Emmahaven menuju Tanjung Priok di Batavia, kemudian melanjutkan perjalanannya dengan kereta api uap menuju Stasiun Tugu Yogyakarta.

Merintis Groep Kurai Taji dan
Mengikuti Kongres Muhammadiyah Selama bermukim di Yogyakarta, Ilyas tidak menyiakan kesempatan untuk mendalami keMuhammadiyahan. Selain aktif mengikuti kegiatan Hizbul Wathan, selama setahun bermukim di Yogyakarta, ia juga aktif menimba ilmu kepada founder Muhammadiyah $\mathrm{KH}$. Ahmad Dahlan. Satu tahun lamanya, Ilyas mendalami Matan Keyakinan dan Cita-cita Hidup Muhammadiyah, Kepribadian Muhammadiyah, dan mengikuti kajian Ahmad Dahlan.

Pada tahun 1929 Ilyas memuntuskan pulang ke Kurai Taji dan segera mendirikan Groep Muhammadiyah. Perjuangannya untuk mendirikan Muhammadiyah bersama Haji Haroen el Maany, Oeddin, Haji
Umar Ganti, Sulaiman Munafy, Kasim Munafy, Abdul Jalil, dan lainnya memang berat, karena mendapat respon keras dari kalangan ulama tarekat Syattariyah. Bahkan, ketika Muhammadiyah diresmikan tanggal 29 Oktober 1929 di garasi mobil Bagindo Moh. Tahar, harus dikawal sejumlah orang parewa dan jago silat, agar tidak diganggu oleh massa fanatik Syattariyah (Munafy, 1979).

Sebulan kemudian, Ilyas yang terpilih sebagai Ketua Groep Muhammadiyah Kurai Taji kembali ke Jawa, untuk mengikuti Kongres Muhammadiyah ke-18 di Solo. Dari Sumatera Westkust, utusan yang menghadiri Kongres antara lain: Cabang Sungai Batang, Padang Panjang, Simabur, Bukittinggi, Padang (luar kota), Pariaman (Kuraitaji) dan Lakitan (Bandar X). Uniknya dalam Kongres ke18, masing-masing peserta diwajibkan memakai busana tradisional, untuk menandai identitas lokalitasnya. Foto yang pernah dimuat oleh Blumberger memang unik. Seluruh utusan berbusana adat daerah masing-masing-sesuai anjuran Hoofdbestuur Muhammadiyah Hindia Timur. Yang unik adalah beberapa utusan di luar Sumatera Barat, namun notabenenya adalah orang Minang memakai pakaian khasnya, bukan menurut daerah yang mengutusnya. Ilyas Sutan Perpatihketua Cabang Muara Aman dan Abdul 
Wahid ER, ketua Cabang Pagar Alam- Batang Tanjung Sani Maninjau. merupakan putra kelahiran Sungai

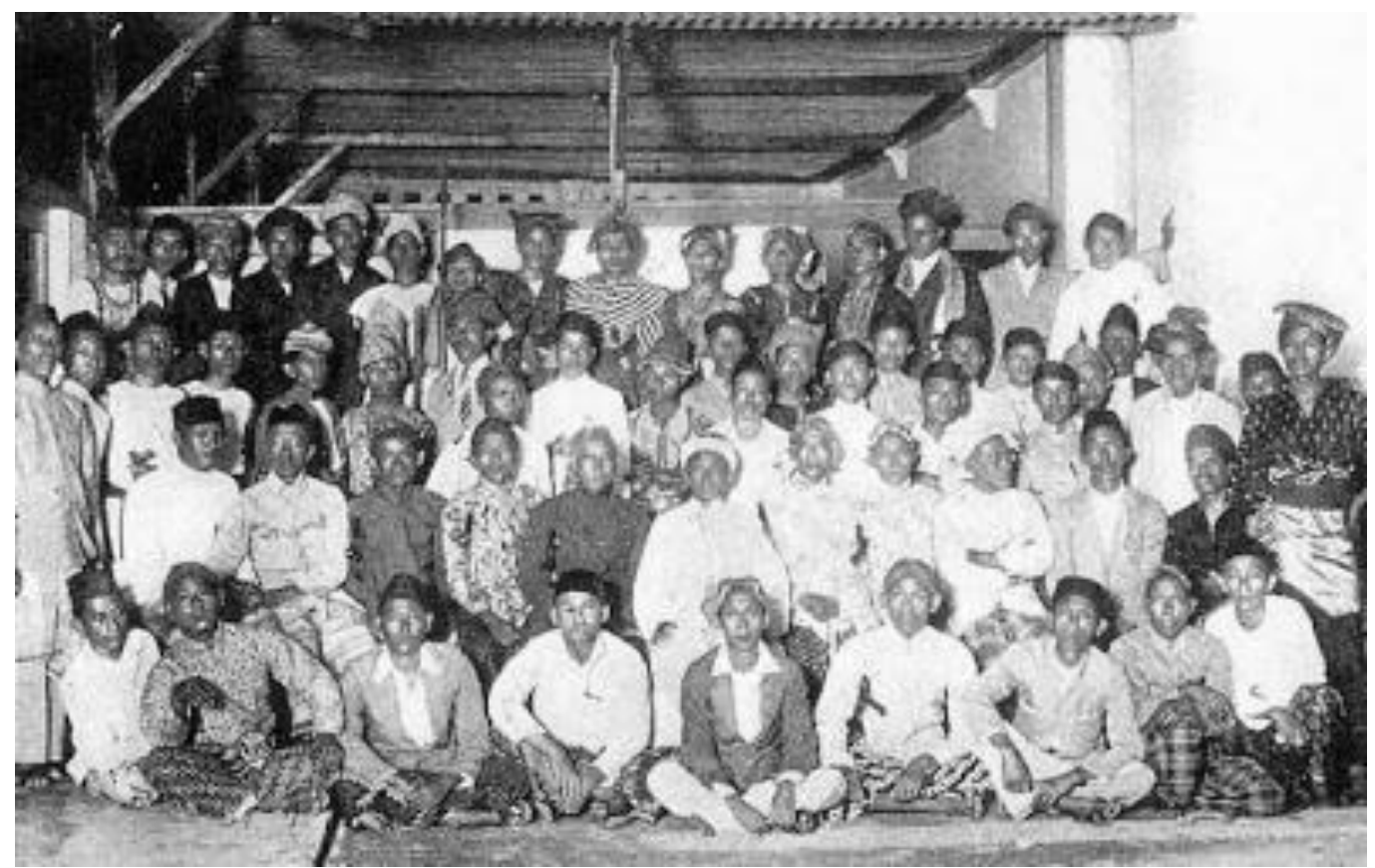

Gambar 2. Kenangan Kongres ke-18 tahun 1929 di Solo. Masing-masing daerah memakai busana daerahnya masing-masing. Sumber: Direproduksi dari J. Th. Petrus Blumberger, 1935.

Ketika Kongres ke-18 khusus membahas agenda pelaksanaan kongres ke-19, Haji Fachrudin mengutarakan pengalaman empirisnya selama di Sumatera Barat. la mengusulkan, agar menetapkan Sumatra Westkust sebagai pelaksana kongres selanjutnya. Fachruddin beralasan, daerah tersebut merupakan negeri yang mampu memenuhi cita-cita Muhammadiyah, sekaligus pelopor pengemba-ngan persyarikatan di seluruh Sumatera, bahkan seluruh Hindia Timur (Hamka, 1960: 42).

Usulan Haji Fachrudin rupanya mendapat sambutan hangat dari M.Joenoes Anis, dan seluruh utusan dari daerah. Ketika pimpinan sidang meminta kesediaan utusan Minangkabau, mereka pun meminta waktu untuk membicarakannya di Konferensi Daerah. Namun jawaban utusan itu, ditanggapi dengan penuh semangat oleh Haji Fachrudin.

"Kalau Muhammadiyah
Minangkabau tidak sanggup
mengadakan Kongres ke-19,
Pengurus Besar akan mengadakan
juga Kongres di Minangkabau, dan
minta bantu kepada saudara-
saudara di Minangka-bau untuk
jadi panitia!" (Hamka, 1960: 43)

Pasca Kongres ke-18 dan Konferensi Daerah di Simaburmemutuskan perhelatan akbar akan dilaksanakan tanggal 14-21 Maret 1930 di Bukittinggi, para pimpinan Muhammadiyah bekerja keras untuk 
menambah jumlah ranting (groep). Hamka mengisahkan, untuk 'salingkaran' Maninjau telah berdiri groep Tanjung Sani, Pandan, Galapung, Batu Nanggai, Muko Jalan, Sigiran, Airikir Koto Panjang, dan seluruh nagarinagari di Bukittinggi. Pengurus Muhammadiyah cabang Bukittinggi, kemudian ikut merintis groep Sibolga dan Sipirok. Sedang-kan Hamka sendiri mendirikan groep Lakitan Pesisir Selatan. Sehingga jelang kongres Muhammadiyah, untuk Sumatera Barat telah berdiri di 27 daerah. Berbeda dengan llyas, yang berupaya keras membangun amal usaha Muhammadiyah.

\section{Membangun Surau Dagang}

Surau Dagang merupakan amal usaha pertama yang dimiliki Muhammadiyah Groep Kurai Taji, dalam lembar sejarahnya memiliki kisah unik. Surau Dagang didirikan di tanah wakaf milik kaum Koto dan disetujui pembangunannya oleh Mak Dorong, Mak Demak, Moh. Ma'ruf dan Syamsudin pada tahun 1928. (Munafy, 1995: 13).
Setelah didirikan, Surau Dagang belum menyelenggarakan shalat Jumat, mengingat, seluruh masyarakat Kurai Taji melaksanakannya di Mesjid Punago Panendangan. Otoritas tertinggi mesjid berada di tangan Tuanku Kali yang bermukim di Lubuk Ipuh, dan berafiliasi pada tarekat Syattariyah. Sehingga kelompok Islam tradisional ini sering dipanggil urang Kuno atau Kaum Tua. (Abdullah, 1987).

Untuk menyebar berita keberadaaan Muhammadiyah di Mesjid Punago, Ilyas dan pengurus Groep Kurai Taji berusaha mendekati Tuanku Kali Lubuk, dengan harapan mereka diberi kesempatan menjadi khatib Jumat. Lebih lanjut Kasim Munafy (1995: 1) dalam manuskripnya menulis:

Oleh pengurus Muhammadiyah Groep Kurai Taji telah dicoba mendekati ninik mamak dan tuanku kali untuk mulai mengadakan perubahan untuk kemajuan beragama, khususnya mendekati Sunnah Rasul. Khusus dalam pelaksanaan khutbah supaya dilaksanakan dengan memakai bahasa Indonesia, agar tujuan khutbah dapat dimengerti oleh jamaah. 


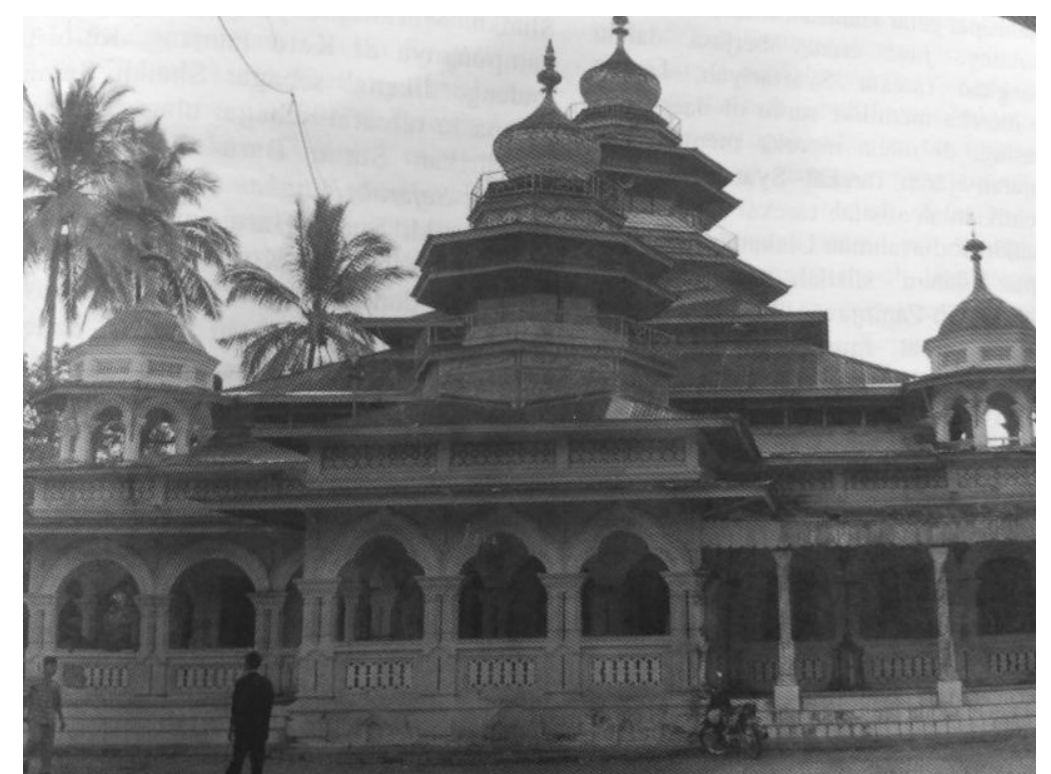

Gambar 3. Mesjid Raya Raya Punago Panendangan-pada awal berdirinya Muhammadiyah telah menjadi sentral pelaksanaan ibadah Jumat di Nagari Kurai Taji. Sumber: Direpro dari Fathurrahman, 2005.

Lewat negoisasi alot dan mendapat serangan verbal dari Kaum Tua, Tuanku Kali pun menyetujui usul pengurus Muhammadiyah Kurai Taji. Namun, dalam praktiknya, ulama Syattariyah sering mengingkari kesepakatan. Lebih lanjut Kasim menulis,"Mula-mula didapat satu modus, ialah dengan cara bergantian khutbah. Kalau Jumat pertama dilaksanakan oleh imam khatib dari kaum tua (di bawah kuasa Tuanku Lubuk Ipuh), maka Jumat kedua pelaksanaannya akan berada di bawah kaum muda, oleh Muhammadiyah. Modus ini dapat dipahami oleh pengurus Muhammadiyah di masa itu dan diterima. Namun, dalam pelaksanaannya terjadi yang bukan dikehendaki, ialah kalau datang giliran bagi pelaksanaan cara baru,kehadiran kaum tua tak ada kelihatan lagi. Kasim Munafy,"Kenapa
Muhammadiyah Kuraitaji Bertekad Membangun Mesjid?".

Pada awal bulan, khutbah diisi oleh Tuanku Kali Lubuk Ipuh dan diikuti oleh pengikut Muhammadiyah. Namun, giliran khutbah dilaksanakan pengurus persyarikatan, kaum tua dan pengikutnya itu melaksanakan salat Jumat di Surau Lubuk Ipuh.

Mula-mula didapat satu modus, ialah dengan cara bergantian khutbah. Kalau Jumat pertama dilaksanakan oleh imam khatib dari kaum tua (di bawah kuasa Tuanku Lubuk Ipuh), maka Jumat kedua pelaksanaannya akan berada di bawah kaum muda, oleh Muhammadiyah. Modus ini dapat dipahami oleh pengurus Muhammadiyah di masa itu dan diterima. Namun, dalam pelaksanaannya terjadi yang bukan dikehendaki, ialah kalau datang giliran bagi pelaksanaan cara baru,kehadiran kaum tua tak ada kelihatan lagi.

Melihat gelagat dan kecurangan dari Kaum Tua, Ilyas dan pengurus lainnya kembali menemui Tuanku Kali Lubuk 
Ipuh. Dari hasil pembicaraan tersebut, keluar dua putusan. Pertama, kaum tua setuju dengan khatib bergilir setiap bulannya, meskipun dalam pelaksanaannya mereka tetap tidak mau mengikuti ibadah Jumat, bila kesempatan itu digelar Muhammadiyahdengan alasan tidak sesuai dengan ajaran Syattariyah. Kedua, mengizinkan pihak Muhammadiyah groep Kurai Taji melaksanakan ibadah Jumat di Surau Dagang. Sejak saat itu, pengurus Muhammadiyah Groep Kurai Taji resmi melaksanakan ibadah Jumat di Surau Dagang pada awal 1930 (Sufyan, 2003).

Gambar 4. Kasim Munafy (pakai peci) berfoto bersama dengan anak-anak Panti Asuhan Muhammadiyah di depan Surau Dagang pada tahun 1985. Sumber Repro Dokumentasi Kasim Munafy.

\section{Mendayagunakan Tanah Wakaf Haji Mangan}

Selain mengubah status Surau Dagang menjadi mesjid, di bawah pimpinan lyas, Muhammadiyah mendayagunakan tanah-tanah wakaf yang diberikan oleh tokoh masyarakat Kurai Taji. Sumbangan terbesar diberikan oleh Haji Mangan, seorang saudagar kopra yang merupakan kakak ipar Ilyas. Tanah yang diwakafkan oleh Haji Mangan nantinya diperuntukan bagi pembangunan rumah yatim Muhammadiyah dan gedung Madrasah
Tsanawiyah, yang terletak di tengah sawah.

Sebelum pembangunan gedung, pada tahun 1930 atas prakarsa Ilyas dan jajarannya, melaksanakan Shalat Idul Fitri pertama di tanah wakaf Haji Mangan. Sehari sebelum pelaksanaan shalat, pengurus Muhammadiyah, menyebar surat himbauan kepada masyarakat Kurai Taji, agar melaksanakan salat sesuai dengan anjuran Rasulullah saw, yakni di tanah lapang. 
Dalam manuskripnya, Kasim Munafy menarasikan himbauan pimpinan persyarikatan, bahwa masyarakat yang datang ke tanah lapang dianjurkan untuk berbaris rapi sambil mengumandangkan takbir. Rombongan jamaah shalat led, yang datang silih berganti itu, diatur oleh pimpinan persyarikatan, berasal dari surau Paninjauan, surau Dagang, dan surau Apar Batangtajongkek. Sebagai pemateri khutbah pada masa itu, didaulat Haji Haroel el Maany-Direktur Kulliyatul Muballighin Muhammadiyah Padang Panjang. Saat pelaksanaan shalat led, para veldpolitie tampak sibuk menjaga jamaah, dari gangguan pengikut kaum kuno.

Setahun menjabat Ketua Groep Muhammadiyah Kurai Taji, Ilyas melepas masa lajangnya dengan mempersunting gadis asal Kuraitaji bernama Rohana (Ikhwan, 2005). Dalam tradisi perkawinan Pariaman, dikenal istilah ba japuik atau ba bali-semacam tradisi di mana pihak mempelai perempuan mesti menyediakan sejumlah uang atau emas yang digunakan untuk meminang mempelai laki-laki. Pada masa perkawinan Ilyas, keluarga Rohana mengeluarkan beberapa ameh (1 ameh setara dengan 2,5 gram emas). Besaran emas itu, juga dilihat dari status sosial dari ayah mempelai laki-laki, semakin tinggi gelarnya, makin tinggi nilai jemputan untuk anaknya. Setelah resmi menikahi Ilyas, keluarga besar Rohana memanggil gelar yang melakat pada suaminya, yakni Sidi. Sejak itu sampai akhir hayatnya, namanya selalu ditulis Sd.Mhd.Ilyas. Dan, Rohana sejak awal menikah telah dianjurkan oleh Sidi $M$. Ilyas untuk aktif di organisasi Aisyiyah. Berikut struktur genealogi pernikahan Ilyas dengan Rohana.

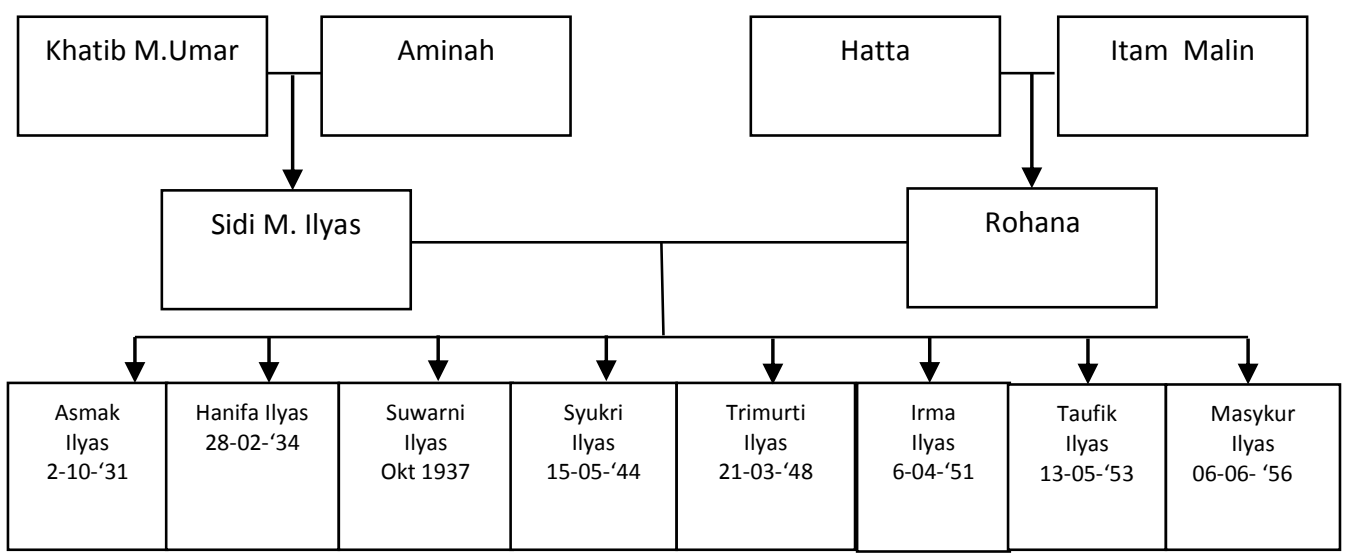

Sumber: Diolah dari Ichwan, 2005. 


\section{Mendirikan Rumah Yatim Muhammadiyah}

Selain memanfaatkan tanah wakaf, Haji Mangan juga menyerahkan rumah eks pemilik pabrik minyak kelapa, yang dibelinya dari seorang Controleur. Rumah inilah yang dipakai Sd.Mhd. Ilyas sebagai kantor Muhammadiyah Groep Kurai Taji, sekaligus menampung puluhan anakanak yatim. Sehingga rumah ini dikenal sebagai internaat Yatim Muhammadiyah Kurai Taji.

Kemasyhuran internaat Yatim Muhammadiyah dikenal dengan baik, dalam catatan sejarah Kongres Muhammadiyah ke-19 tahun 1930 di Bukittinggi. (Munafy, 1985) Puluhan anak-anak yatim itu dibawa oleh Ilyas dan Kasim Munafy, untuk memeriahkan even akbar PB Muhammadiyah yang dilaksanakan lima tahun sekali.

Penyelenggaraan Kongres ke-19 merupakan bukti suksesnya Muhammadiyah di Minangkabau. Alasan pemilihan Minangkabau sebagai penyelenggara, karena daerah ini produsen ulama modernis dan masyarakatnya cepat menerima pengaruh Muhammadiyah. Di samping itu, perkembangan Muhammadiyah Minangkabau dinilai jauh lebih pesat dibandingkan daerah asalnya (Hamka, 1974).

Suasana pembukaan kongres Muhammadiyah yang meriah itu dideskripsi-kan dalam laporan Hoofdcomite tahun 1930. Utusan tiaptiap daerah diminta mengenakan pakaian adat masing-masing pada pembukaan kongres. Seruan itu pun dipatuhi semua utusan. Dalam laporan itu dinarasikan, bahwa utusan Kuala Kapuas memakai pakaian adat Dayak, Haji Yunus Jamaluddin dari Bengkulu memakai Saluk Timba, Sutan Perpatih dari Muara Aman memakai pakaian Rejang, dan utusan dari Makasar memakai lenso celana pendek, sarung bugis disisipi sebilah badik (Hoofdcomitte Congres Moehammdijah Djogdjakarta 1931). Dalam acara pembukaan Kongres ke-19 itu, rombongan anak yatim yang dibawa Ilyas menyanyikan lagu mars Yatim Kurai Taji.

Kami ini yatim piatu

Tiada bapa tiada ibu

Tiada orang yang akan membantu

Bagaimana nasib belumlah tentu. (Munafy, 1995: 13)

Masih dalam acara yang sama, seorang perwakilan anak yatim berpidato di depan seluruh peserta kongres. Munafy yang masa itu masih berusia 13 tahun, menyaksikan banyak di antara peserta kongres menitikkan air mata, mendengar pidato tersebut. Suasana haru meliputi para peserta yang mengingatkan pada teologi surat AlMa'un yang sering ditekankan $\mathrm{KH}$. Ahmad Dahlan. 
Membangun Sekolah Pasca Kongres ke19

Pasca Kongres Muhammadiyah di Bukittinggi, Ilyas dan pengurus Groep Kurai Taji kembali mengembangkan amal usaha persyarikatan, di antaranya membangun Woestaschool (sekolah kelas satu) dan Schakel School (sekolah lanjutan kelas 2). Catatan mengenai keberadaan Schakel School ini terungkap dari manuskrip Kasim Munafy (1995: 23) yang mengisahkan pendidikannya dari Twee Class School menyambung ke Schakel School yang masa itu berada di Kota Pariaman.

Selanjutnya pada tahun 1934, pimpinan Muhammadiyah Groep Kurai Taji mendirikan sekolah Tsanawiyah yang ditujukan untuk menampung lulusan Schakel School. Untuk menampung pelajar, terutama yang berdomisili di Ampalu, Sunur, Sungai Sariak, Tandikat, Kampung Dalam, dan dari Darek (pedalaman Minangkabau), pengurus Muhammadiyah mendirikan asrama (internaat). Para pengajar di sekolah ini antara lain: Sulaiman Munafy, Abdul Jalil, M. Thahar Rahmat dan lainnya. Keberadaan sekolah ini terekam jelas dalam iklan Bahtera Massa yang diterbitkan Muhammadiyah Cabang Pariaman pada tahun 1936.

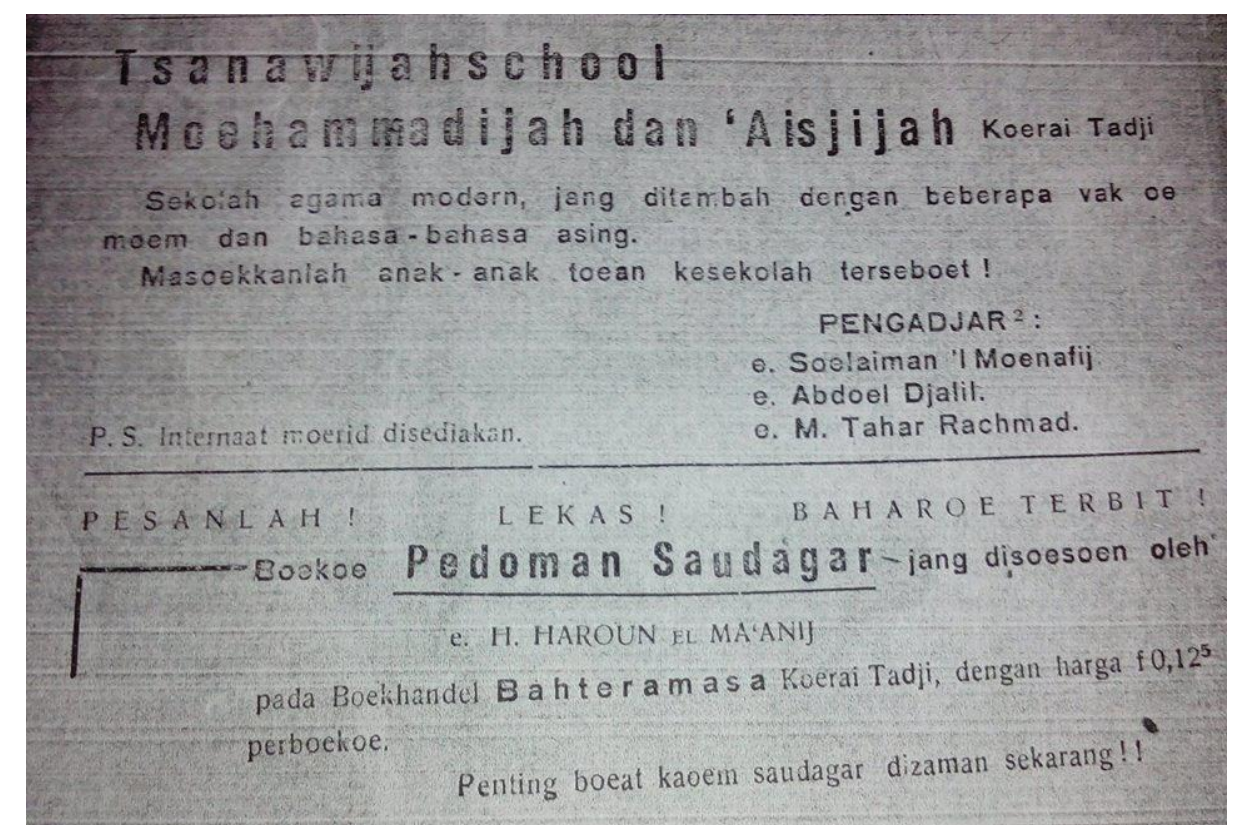

Gambar 5. Iklan Sekolah Tsanawiyah Muhammadiyah Kurai Taji pada tahun 1936. Dalam manuskrip Kasim Munafy dijelaskan, bahwa Bahtera Massa dalam penerbitannya dibiayai oleh Sd.Mhd. Ilyas. Sumber: Bahtera Massa No.1 Februari 1936.

Tingginya aktivitas Ilyas dan Rohana memang diakui oleh anak-anaknya. Asma' Ilyas putri pertama mereka mengakui, orang tuanya menikah ketika krisis malaysie atau yang dikenal sebagai resesi ekonomi menghantam 
dunia secara keseluruhan. (Asma' Ilyas, wawancara, tanggal 22 Januari 2017 di Rawamangun Jakarta Timur). Dan, pemerintah Kolonial Belanda membutuhkan waktu lama, untuk memulihkan situasi ekonomi yang buruk. Untuk menghidupi keluarganya, Ilyas dan Rohana berjibaku untuk mengatasi kesulitan ekonomi. Kesibukan Rohana sebagai ibu rumah tangga, makin bertambah ketika menjabat Ketua Aisyiyah ranting Kurai Taji pada tahun 1931 menggantikan Gadis Gapuk yang hanya menjabat selama setahun. Rumah Rohana yang berada dekat simpang Bazoka tersebut, hampir setiap hari menjadi tempat berkumpulnya aktivis Muhammadiyah dan Asiyiyah.

Aktivis Muhammadiyah yang sering bertandang ke rumah mereka antara lain H. Abdul Malik Karim Amrullah (HAMKA), Abdul Malik Ahmad, Haji Haroen el-Maany, M. Louth Hasan, Sulaiman Munafi, Kasim Munafy, Haji Umar Ganti, Abdul Jalil, dan lain sebagainya. Sedangkan seluruh aktivitas Aisyiyah berlangsung di rumah Rohana, mulai dari menjahit, menenun, membuat kue, berorganisasi, dan lain sebagainya (Asma' Ilyas, wawancara, tanggal 22 Januari 2017). Senada dengan Asma' Ilyas, Hanifah juga mengungkap hal yang sama. Hanifah menjadi saksi aktivitas Aisyiyah di rumahnya, lebih lanjut ia mengisahkan.

Tiap-tiap konferensi Aisyiyah, selalu keramaian aktivitas itu di rumah saya. Tapi kalau aktivitas ibu-ibu Aisyiyah sepi, rumah kami itu diramaikan oleh tokoh Muhammadiyah. Makanya, kami akrab dengan tokoh-tokoh Muhamamdiyah itu, termasuk dengan Buya Hamka.

Hanifah dan saudaranya menyadari, kesibukan kedua orang tuanya merintis Muhammadiyah-Aisyiyah dari awal hingga berkembang cukup pesat. la hampir setiap hari melihat ayahnya sibuk mengurus organisasi, menyebarkan paham modernism Islam lewat khutbah dan ceramahnya, hingga membangun amal usaha Muhammadiyah Groep Kurai Taji. (Hanifah llyas, wawancara, tanggal 20 Januari 2017 di Pamulang Barat, Tangerang Selatan).

Memasuki tahun 1935, Ilyas menikah untuk kali kedua dengan Nur'ain binti Magek asal Marunggi Pariaman. Nur'ain, perempuan kelahiran 14 Desember 1917 sendiri merupakan lulusan dari sekolah Khadijah School yang didirikan pimpinan Muhammadiyah Groep Kurai Taji. Dalam pernikahan ini, lahirlah sembilan orang anak, yakni Rusyda Ilyas (23 Agustus 1936), Nurlis Ilyas (7 Agustus 1938), Djoesma Ilyas (13 Juli 1940), Hasni Ilyas (16 Oktober 1942), Rusjdi Ilyas (8 Desember 1944), Husni Ilyas (6 Maret 1947), Mursyid Ilyas (19 Mei 1947), Elvi Ilyas (6 November 1952), dan Nelly Olivia Ilyas (07 Juli 1955). (Ichwan, 2005: 5). Pasca menikah dengan isteri kedua, Ilyas memboyong Nur'ain ke Kisaran Sumatra Timur, sedangkan 
Rohana memutuskan menetap di Kurai Taji karena masih sibuk membesarkan Aisyiyah yang telah naik statusnya menjadi Cabang.

\section{Muhammadiyah Pariaman Sepeninggal Ilyas}

Meskipun sudah jauh dari Kurai Taji, Ilyas masih mengikuti perkembangan persyarikatan. Ketika statusnya naik menjadi sebagai cabang, diperkirakan anggota Muhammadiyah Kurai Taji telah mencapai ratusan orang. Pimpinan Cabang Muhammadiyah Pariaman terdiri dari:

Ketua : Oedin

Sekretaris: M. Louth Hasan, dan

Anggota : Abu Bakar Maaruf, Sulaiman Munaf, Abdul Jalil, dan Thaher Rahmat (Munafy, 1995: 13).

Setelah naik status menjadi Cabang Pariaman, Oedin mulai melakukan gebrakan mendirikan beberapa ranting, mulai dari Lubuk Alung dan Sungai Sarik Malai, di samping persyarikatan juga telah memiliki beberapa amal usaha, seperti sekolah lanjutan (Sufyan, 2003).

Kisah perjuangan mendirikan ranting Sungai Sarik Malai dimula dari tourne Oedin dan M. Louth Hasan yang mengendarai kuda bendi dari Kuraitaji. Keduanya baru sampai ditujuan pada senja hari dan disambut di pekarangan rumah Bagindo Bisu. Rupanya sudah banyak yang menantikan kehadiran pengurus Muhammadiyah Cabang Pariaman, tulis Kasim Munafy dalam manuskripnya, di antaranya dari keluarga sponsor dan beberapa penghulu Malai V Suku. (Munafy, 1995: 13). Lebih lanjut, informan yang berada di Sariak Malai V Suku menerangkan, bahwa sponsor yang dimaksud Kasim dalam manuskrip itu, antara lain: Abdul Razak, Tuanku Itam Bujang, dan Buyung Enek Marajo (M. Yasin, wawancara, tanggal 29 Oktober 2017 di Sariak Malai V Suku Timur.)

Setelah sampai di tujuan, Oedin langsung berdiskusi dengan para penghulu, untuk menjelaskan kedatangan mereka. Namun, para penghulu Sariak Malai V Suku menolak keinginan pengurus Cabang Pariaman untuk mendirikan ranting Muhammadiyah Sungai Sarik Malai. Mendapat respon penolakan itu, Oedin hanya berujar,

"Kalaulah engku Ninik Mamak kami disini yang melarang untuk berdirinya Muhammadiyah di sini, apalah daya kami. Kami sebagai kemenakan Ninik Mamak, tentulah akan mengambil perhatian tentang pedirian Ninik Mamak kami itu." (Munafy, 1987: 1). 


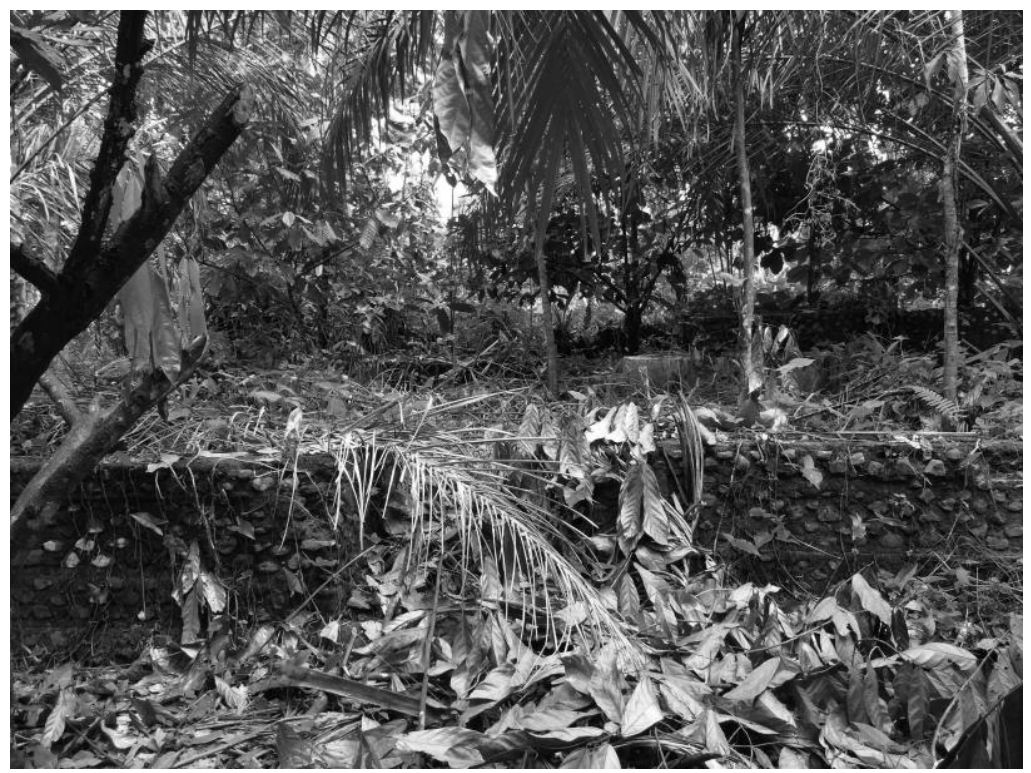

Gambar 6. Bekas rumah Buyuang Enek Marajo yang menjadi saksi lahirnya ranting Muhammadiyah Sariak Malai V Suku. Sumber: Dokumentasi Fikrul Hanif Sufyan.

Rupanya tidak sampai disana saja, ninik mamak Malai $\vee$ Suku juga keberatan, apabila Oedin dan Louth Hasan menginap di rumah Bagindo Bisu, sehingga terjadi dialog yang cukup alot.

Penghulu : Tempat bermalam
angku-angku di rumah
Bagindo Bisu itu pun tak
boleh. Engku-engku
harus kembali ke
Kuraitaji sekarang juga.
:
Kalau itu yang engku-
engku perintahkan
kepada kami, itu tidak
mungkin dapat kami
penuhi.
pikirkan, baru sebentar
ini kami sampai kemari
dan baru buka pakaian
kuda bendi, belum lagi
kering peluh kuda
setelah menempuh jarak
yang tak kurang dari 30
kilometer, sekarang
haruus and memaksa
kembali kuda berlari ke
Kuraitaji.
Ini rasanya cukup berat
bagi kami, apalagi bagi
kuda yang akan berlari.
Adapun masalah kami

akan bermalam di rumah Bagindo Bisu ini, senadainya mamak melarang kami, kami dapat mematuhi. Carikanlah kami rumah lain atau bersama engku-engku Ninik Mamak kami bermalam di sini. Kami bersedia saja, asal kami tidak diperintah harus kembali sekarang juga ke Kurai Taji.

Penghulu : Nah, kalau begitu baiklah. Engku-engku yang datang dari Kurai Taji kami benarkan bermalam di rumah Bagindo Bisu. Dan, nanti malam setelah makan, minum, dan sembahyang Isya lampu dipadami dan engku-engku tidur di sini (Munafy, 1987: 2).

Ketika malam datang, Oedin kembali mengingatkan kepada para penghulu yang menunggu di beranda rumah, bahwa mereka akan beristirahat. Salah seorang penghulu 
kemudian berujar,"Baiklah, kami akan berjalan lagi meninggalkan rumah ini.Dan, matikanlah lampu.".

Pasca rombongan penghulu meninggalkan rumah Bagindo Bisu dan lentera sudah dipadamkan, Oedin kemudian bicara pelan kepada yang hadir di rumah itu."Saudara-saudara sekalian, Kan sama didengar patokan dari ninik mamak tadi, bahwa pertemuan umum malam ini untuk mendirikan Muhammadiyah tidak boleh kita laksanakan. Tapi, saudara-saudara harus tau, bahwa mendirikan Muhamamdiyah itu tidak mesti dalam pertemuan umum juga. Yang penting ada anggota Muhammadiyah yang akan bertanggungjawab setelah berdirinya Muhammadiyah itu nanti. Sekarang, terserah kepada saudara-saudara sekalian, apa Muhammadiyah Sariak Malai itu akan berdiri juga, atau tidak!”. Sampai akhirnya terjadi dialog menjelang seluruh penghuni rumah itu terlelap tidur.

Peserta: lyo engku. Muhammadiyah wajib berdiri di nagari kito ko. Kudian (kemudian) kito hitung parkaro (perkara).
Oedin kemudian memukul lantai papan rumah tiga kali, tanda disahkannya ranting Sariak Malai V Suku.

Oedin: Besok pagi, kami berdua akan kembali ke Kurai Taji. Dan, sepeninggal kami nanti naikkan plang merk Muhammadiyah tanda berdirinya di nagari kita ini. Engku-engku semua sebagai anggota Muhammadiyah di sini akan memperhatikan dan bertanggung jawab. Siapa yang menurunkan plang merk Muhammadiyah itu, nanti akan kita hadapi sesuai aturan Staatsblad. (Munafy, 1987: 3)

Besarnya perhatian Ilyas terhadap Muhammadiyah Pariaman, dibuktikanya dengan ikut mensponsori dan membiayai pers Bahtera Massa. Pers yang disponsori oleh Ilyas ini, bisa dikatakan satu-satunya pers yang diterbitkan groep Muhammadiyah Sumatera.

Kisah mengenai penerbitan Bahtera Massa, bermula dari ide Kasim, Aburahym Raschid, Nurdin PC, dan beberapa pemuda lainnya setelah melaksanakan salat Isya di belakang bengkel Apar Besi pada Januari 1936. Kasim awalnya melempar ide untuk menerbitkan majalah dan meminta kesediaan Thaher untuk menjadi pimpinan redaksi. 


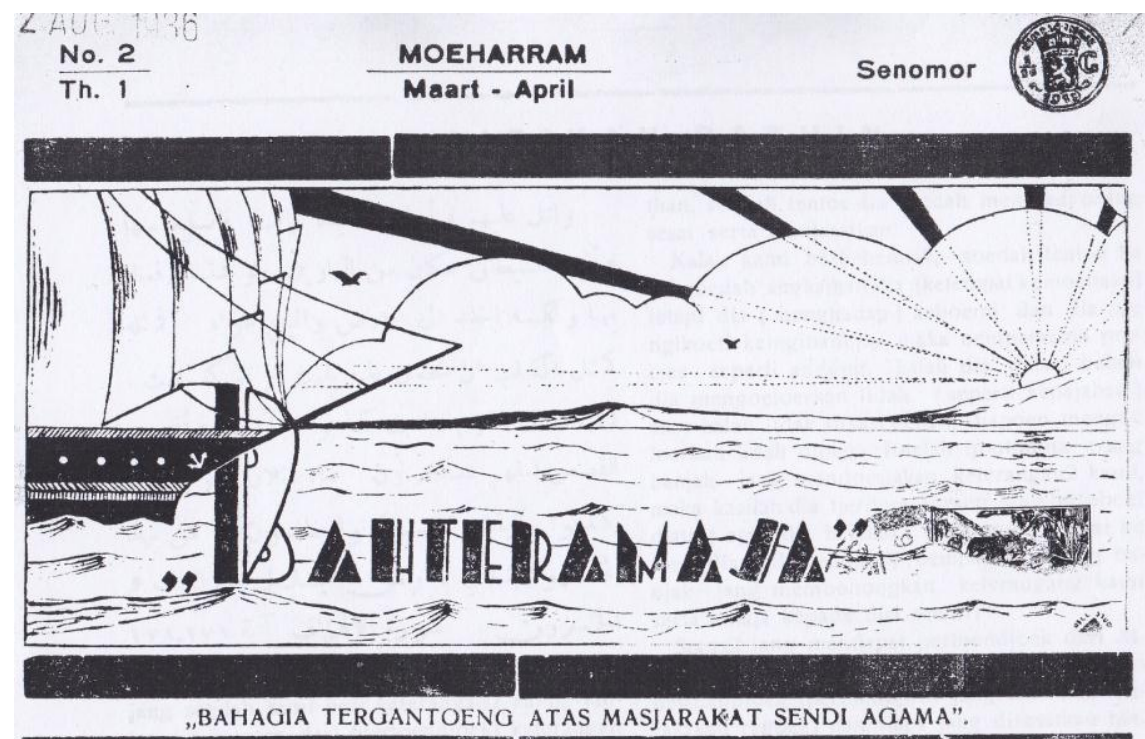

Gambar 7. Bahtera Masa edisi No.2 bulan Maret-April 1936. Pada terbitan ketiga, majalah ini diberangus oleh pemerintah Padang Panjang. Majalah ini dibakar di depan pimpinan Muhammadiyah Konsul Minangkabau Saalah Yusuf Sutan Mangkuto. Sumber: Repro Bahtera Masa edisi No.2 bulan Maret-April 1936

Anggota Pemuda Muhammadiyah akhirnya setuju dengan ide Kasim Munafy dan meminta Sd.Mhd. Ilyas yang berada di Kisaran untuk mendanai penerbitan majalah Bahtera Masa. Edisi awal majalah yang dicetak di Padang Panjang itu tercatat pada bulan Februari 1936 dengan mengusung semboyan 'Bahagia Tergantung Atas Masyarakat Sendi Agama'.

Adapun susunan redaksi Bahtera Masa adalah sebagai berikut, Pimpinan Redaksi: Thaher Rahma; Wakil Pemred: M. Louth Hasan; Anggota: Aburahym Rachid, Sulaiman Munafy, Kasim Munafy Nurdin PC (Bahtera Masa Nomor 2 bulan Maret-April 1936).

Pada edisi perdana Wakil Pemred Bahtera Masa M. Louth Hasan menulis sebuah artikel berjudul Islam dan Perdamaian. Dalam artikelnya Louth Hasan mengingatkan agar perpecahan yang terjadi di antara bangsa-bangsa Islam di dunia harus secepatnya diatasi. la menulis, "satu bangsa dengan bangsa sama-sama bermain mata ibarat kucing dan tikus, disaat kucing telah pandai berjalan di atas peran, tikus berdaya upaya berjalan di atas tali." (Bahtera Masa Nomor 1 edisi Februari-Maret 1936). Selain M. Louth Hasan, Kasim Munafy juga ikut menulis Surat-surat R.A Kartini di Bahtera Masa. la mengalih-bahasakan tulisan Kartini yang awalnya berjudul Door Duisternis Tot Licht.

Namun penerbitan Bahtera Masa hanya berjalan selama bulan Februari dan Maret saja. Ketika menginjak pada bulan April 1936 majalah Bahtera Masa pun dibredel oleh pemerintah Afdeeling Tanah Datar. Sebelum dinyatakan 'dilarang' oleh pemerintah, pimpinan Muhammadiyah Konsul Minangkabau 
Saalah Yusuf Sutan Mangkuto dipanggil oleh kepala PID Belanda di Padang Panjang. Setelah mendengar keterangan dari kepala PID edisi ketiga Bahtera Masa pun dibakar di depan Saalah Yusuf (Munafy, 1984: 2) Dua hari setelah pembredelan Bahtera Masa, pimpinan Muhammadiyah Konsul Minangkabau memanggil Wakil Pemred M. Louth Hasan. Saalah Yusuf menerangkan, bahwa sebab dibakarnya majalah itu bermula dari permintaan Wakil Controleur Padang Panjang terhadap isi majalah Bahtera Masa.

\section{PENUTUP}

\section{Simpulan}

Sidi Mhd. Ilyas pendiri Muhammadiyah Group Kurai Taji barangkali sedikit dari pemimpin persyarikatan yang mempunyai tiga kemampuan berbeda. Dikenal sebagai seorang organisatoris, ulama, pendidik, juga aanemer (kontraktor bangunan). Dibesarkan dalam lingkungan tradisi tarekat Syattariyah masih kental pada masa itu, malah ia memberi warna berbeda dan menawarkan formulasi Islam modernis dalam wadah organisasi Muhammadiyah.

Ketidakpuasannya terhadap persoalan taklid, bid'ah, dan khurafat yang berlangsung sejak lama di pesisir Barat Sumatra, terutama di Pariaman telah mengubah wajah beberapa nagari kearah Islam reformis. Pendekatan humanis yang dilakukannya terhadap ulama-ulama tradisional dan tokoh masyarakat lainnya telah mengubah pandangan, bahwa pembaruan yang dibawa tidaklah mengubah dasar Islam, tapi mengarahkan umat kembali pada Alquran dan Hadits.

Secara bertahap, berdasarkan pengalaman yang ia rasakan selama berada di Yogyakarta dan mengikuti Kongres ke-18 dan ke-19, bersama pengurus Muhammadiyah Groep Kurai Taji merintis amal usaha. Sampai kini persyarikatan telah memiliki 7 Cabang dan 44 ranting yang tersebar di seluruh nagari, kelurahan, dan kecamatan. Selain itu, Muhammadiyah Pariaman telah menghasilkan ratusan amal usaha yang yang bergerak di bidang pendidikan, sosial, kesehatan, ekonomi, dan memiliki puluhan masjid dan musalla. Namun, bisakah generasi penerus yang duduk di pengurus Muhammadiyah Daerah Padang Pariaman mampu merawat semangat untuk ber-Muhammadiyah?. Hanya waktu yang bisa menjawabnya.

\section{DAFTAR PUSTAKA}

\section{Arsip dan Dokumen}

Asmak Bakri. (2010). "Sejarah Aisyiyah di Pariaman dan Sekitarnya.", Manuskrip. Rambai Kurai Taji.

Kasim Munafy. (1979). "Muhammadiyah Yang Aku Kenal.", Manuskrip Sejarah Kehidupan Pribadiku Kasim Munafy Kurai Taji.

Kasim Munafy. (1984). "Menerbitkan Majalah Bahtera Masa. Sesama Pemuda" Manuskrip Sejarah 
Kehidupan Pribadiku Kasim Munafy. Kuraitaji.

Kasim Munafy. (1987). "Taktik Buya Oeddin Mengembangkan Muhammadiyah". Manuskrip Sejarah Kehidupan Pribadiku Kasim Munafy. Kuraitaji.

Kasim Munafy. (1995). "Kenapa Diberi Nama dengan Mesjid Sejarah Muhammadiyah?", Manuskrip Manuskrip Muhammadiyah Yang Aku Kenal. Kuraitaji: Tidak Diterbitkan.

Surat Keputusan Menteri Urusan Veteran No.85/G/ KPTS/MUV.1967 tanggal 30 Desember 1967.

\section{Surat Kabar}

Bahtera Massa No.1 Februari-Maret 1936; Nomor 2 edisi Maret-April 1936.

Suara Muhammadiyah No.13/62 tahun 1982.

\section{Jurnal}

Colombijn, Freek. 1996. Padang, Cities (Elsevier), Vol. 13, Issue 4, August.

Dobbin, Christine. 1974. "Islamic Revivalism in Minangkabau at The Turn of the Nineteenth Century,", Modern Asian Studies Vol VIII.

Kathirithamby-Wells, J. 1969, Achehnese Control over West Sumatra up to the Treaty of Painan of 1663, JSEAH 10, 3:453479.

\section{Buku}

Abdullah, Taufik. (1987). Islam dan Masyarakat: Pantulan Sejarah Indonesia (Jakarta: Pustaka Panjimas.

Ichwan, Ardin. (2005). Keluarga Besar Haji Sidi Muhammad Ilyas. Jakarta: Tanpa Penerbit.
Blumberger, Patrice. (1935). De Communistische Beweging in Nederland-Indie. Haarlem.

Cortesão, Armando. (1944). The Suma Oriental of Tomé Pires, London: Hakluyt Society, 2 vols.

Davis, Keith. (1989). Perilaku Dalam Organisasi. Jakarta: Erlangga.

Gibson, lancevich, dan Donnelly, 1996. Organisasi, Perilaku, Struktur, Proses. Jakarta: Binarupa Aksara.

Hamka. (1960). MuhamamdiyahMasyumi. Jakarta: Masyarakat Islam.

Hamka. (1974. Muhammadiyah di Minangkabau. Jakarta: Yayasan Nurul Islam.

Kartodirdjo, Sartono. (1992). Pendekatan IImu Sosial dalam Metodologi Sejarah. Jakarta: Gramedia Pustaka Utama.

Kuntowijoyo. (2003). Metodologi Sejarah. Yogyakarta: Tiara Wacana.

MD, Sagimun. (1982). Katamso. Jakarta: Departemen P\&K.

Peringatan Congres Moehammadijah ke XIX Minangkabau. (1930). Yogyakarta: Hofdcomite Congres Moehammadijah Djogjakarta.

Schrieke, B.J.O. (1973). Pergolakan Agama di Sumatra Barat. Sebuah Sumbangan Bibliografi. Jakarta: Bhratara.

Sufyan, Fikrul Hanif. (2014). Sang Penjaga Tauhid. Studi Protes Terhadap Tirani Kekuasaan. Yogyakarta: Deepublish.

Taufik Abdullah dan Abdurrahman Surjomihardjo, 1985. Ilmu Sejarah dan Historiografi: Arah dan Perspektif. Jakarta: Gramedia Pustaka Utama.

Yunus, Mahmud. (1970). Sejarah Pendidikan Islam di Indonesia. Jakarta: Mutiara.

Skripsi dan Disertasi 
Abdullah, Taufik. (1971). School and Politics: The Kaum Muda Movement in West Sumatra (19271933) Ithaca New York: Modern Indonesia Project, Southeast Asia Program Cornell University.

Sufyan, Fikrul Hanif. (2003). "Organisasi Muhammadiyah Daerah Padang Pariaman Masa Orde Baru (19671998)". Skripsi. $\quad$ Padang: Universitas Andalas. 